NOYA. ONTARIO MUSEUM 
Digitized by the Internet Archive in 2011 with funding from University of Toronto 

LORIS S. RUSSELL

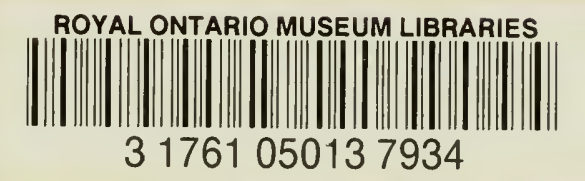

Palaeontology of the Swan Hills Area, North-Central Alberta

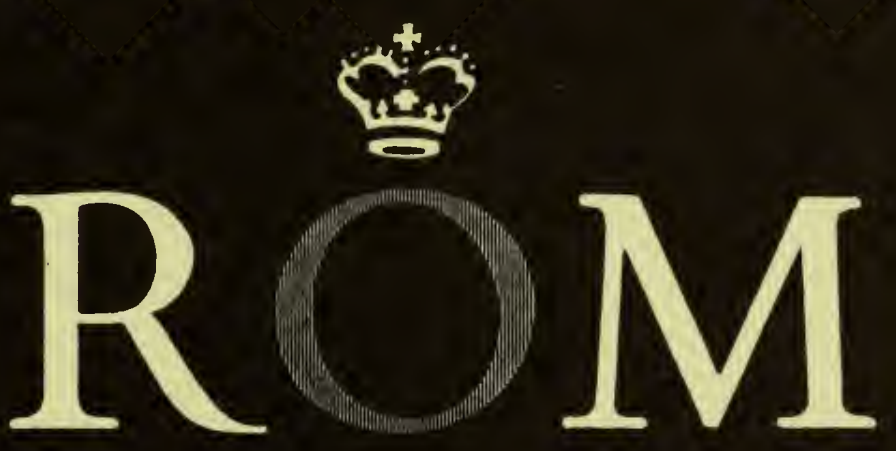



Contribution No. 71

LIFE SCIENCES

ROYAL ONTARIO MUSEUM

UNIVERSITY OF TORONTO

LORIS S. RUSSELL

Palaeontology of the Swan Hills Area, North-Central Alberta

ROYAL ONTARIO MUSEUM

LIFE SCIENCES EDITORIAL BOARD

Chairman: P. C. SWANN

Director, Royal Ontario Museum

Editors: W. B. scot T

Curator, Department of Ichthyology and Herpetology

G. B. WIGG I S

Curator, Department of Entomology and Invertebrate Zoology 
LORIS S. RUSSELL is Chief Biologist of the Royal Ontario Museum and Professor of Geology, University of Toronto.

PRICE： $\$ 1.00$

(C) The Governors of the University of Toronto, 1967

PRINTED AT THE UNIVERSITY OF TORONTO PRESS 


\title{
Palaeontology of the Swan Hills Area, North-Central Alberta
}

\author{
INTRODUCTION
}

Area

THE SWAN HILLS OF ALBERTA are erosion remnants of a once-continuous plateau, lying between Athabaska River on the south and Lesser Slave Lake on the north. The main upland is an east-west ridge, the Swan Hills in the restricted sense. Northeast of this is Deer Mountain, to the north House Mountain, and to the northeast Wallace Mountain, with several lesser uplands between. Elevations rise to over 4,200 feet above sea level on the south, falling off to maxima of about 3,900 on the north. The main drainage is by Swan River and its tributaries, Moosehorn and Inverness Rivers, which flow eastward, then swing to the north to empty into Lesser Slave Lake. The area is well timbered, and lumbering was the main industry before the discovery of oil.

Until recent years the Swan Hills area was one of the more inaccessible parts of northern Alberta. A few wagon roads to forestry lookouts and the forestry patrol trails were the principal means of access. As a result of this inaccessibility, not much was known about the detailed geology. In 1918 J. A. Allan (1919) made a reconnaissance by pack train into Wallace Mountain, and established that the stratigraphical sequence consisted of the Upper Cretaceous Edmonton formation, the Lower Tertiary Paskapoo formation, and a capping of more or less unconsolidated gravels analogous to the Cypress Hills conglomerate of southern Alberta and Saskatchewan. Allan discovered a very rich bed of fresh-water mollusks in the Paskapoo formation on Wallace Mountain, and brought back a good collection. In the matrix were bone fragments, probably of the reptile Champsosaurus.

In 1927 I accompanied R. L. Rutherford on a traverse up Driftpile River from Lesser Slave Lake, but we probably did not get stratigraphically above the Edmonton formation. However, on the basis of Allan's findings it had long seemed important to search for fossils in the higher parts of the Swan Hills. Apart from the difficulties of access, such a search would have been discouraging, because natural exposures of the bedrock were limited to cut-banks on the streams and a few cliffs along the escarpments. This situation has changed radically in the last 10 years.

Interest in the Swan Hills area as a possible oil field led to geological and geophysical exploration by commercial interests in the 1950's, and early in 1959 Home Oil Company and its associates brought in the first 
producing well. Since then extensive drilling has established a major oil field. An all-weather highway links the town of Swan Hills with the railway, and roads of good to fair quality radiate from here for many miles, forming an elaborate network of accessibility. Just as important for the palaeontologist, the construction of roads and the preparation of well and battery sites have involved clearing of vegetation and stripping away of soil. So a host of artificial exposures has been created, most of them accessible by road.

\section{Field work}

On learning of this new situation in 1964, Mrs. Russell and I made two trips to Swan Hills town. On the first of these we encountered a period of rainy weather that made field work impossible. The second visit was almost as unlucky, but one good day allowed us to explore the north slope of the Swan Hills ridge. Here we discovered mammalian remains at an exposure which subsequently yielded the most important material of the area (locality 1). The first identifiable fossil was found by Mrs. Russell, and was such as to permit an immediate identification of the horizon as Middle or Upper Paleocene.

Artificial exposures become slumped and overgrown with vegetation, and unmaintained roads disintegrate, so it seemed important to undertake an immediate and extensive search of the Swan Hills field for fossil vertebrates. A grant was obtained in 1965 from the National Research Council of Canada, with which it was possible to organize a 5-man field party. Objectives of the expedition were three: (1) to obtain additional fossil mammals from the Paleocene rocks so as to confirm the correlation and learn more about the fauna, (2) to locate the higher occurrences of dinosaur bones and so permit an approximate mapping of the CretaceousTertiary boundary, (3) to obtain fossils from the plateau gravels that would permit dating of these deposits.

The first two of these three objectives were achieved, although perhaps not as fully as had been hoped. The Swan Hills area is notorious for heavy rainfall, and the summer of 1965 was unusually wet. A prolonged downpour resulted in overflow of the rivers, and the inundation of our camp site. Even after the heavy rain stopped it was days before the side roads could be used. In spite of these conditions, all but the extreme northern and eastern parts of the field were visited, and a total of 115 artificial exposures were examined. It is hoped in the future to return and examine parts of Deer and House Mountains, especially for possible occurrences of fossils in the plateau gravels.

\section{Methods of work}

Most of the field work consisted of driving or walking to well and battery sites and examining carefully the exposures of bedrock. Concurrently with this, bags of clay from the original discovery site were disintegrated and screened in the river, and the residues searched for fossils. Such work could be carried on when unsettled weather prevented the search for other occurrences. No instrumental surveys were necessary, thanks to the 
excellent topographical maps issued by the Surveys and Mapping Branch of the Department of Energy, Mines and Resources. Maps provided by the oil companies showed the location of roads, wells, and batteries that had been established since the topographical maps were made. Stereoscopic aerial photographs supplemented the maps.

\section{Acknowledgements}

Thanks are first of all due to the National Research Council for providing the funds for the field work. Officials of various oil companies assisted by providing maps and other information on the area and by permitting the use of their private roads. Special mention should be made of Mr. J. L. Carr and Mr. G. C. Beard of Home Oil Limited, Calgary, Mr. A. M. McLachlin of Shell Canada Limited, Edmonton, and Mr. B. K. Moore, Socony Mobil Oil of Canada, Limited, Edmonton. Dr. J. C. Sproule of Calgary, who made the original geological surveys of the area for Imperial Oil Limited, provided helpful information. The entire field party was much indebted to Mr. and Mrs. Ostapek, who operate a saw mill in the Swan River valley. When our camp site was flooded they provided emergency shelter and facilities, so that we were able to resume work as soon as road conditions permitted.

In the course of studying the mammalian fossils I enjoyed the privilege of comparing them with types and other specimens in the American Museum of Natural History, through the courtesy of Dr. Malcolm C. McKenna.

\section{LOCALITIES}

\section{General remarks}

To avoid lengthy repetition of locality data in the text, each locality from which fossils were obtained by the expedition of 1965 has been assigned a number, more or less in order of discovery.

\section{Locality 1}

Legal subdivision 4, Section 16, Township 67, Range 10, West of the 5th Meridian; artificial exposure surrounding site of "Home et al. A Swan Hills" well. This is on the south side of the main road north from Swan Hills town, and is in three parts. To the east of the well is a low bank with the strata somewhat disturbed. The fossils here are mostly the shells of fresh-water mollusks. On the west side the exposure is a road cut, with at least two beds containing fossil shells. Bone fragments occur between and below these beds. On the north side, across a swampy area, is a low crescentic exposure of grey shale with shells and bone fragments. This is the most productive part for fossil vertebrates. Most of the rock at this locality is grey bentonitic shale; there are also thin lignitic layers and beds of friable ironstone. This was the site of the original discovery in 1964. The expedition of 1965 worked the locality intensively. 


\section{Locality 2}

Ls. 12, Sec. 9, Tp. 67, Rge. 10, W. 5th M.; an artificial exposure on the hillside south of a side road leading to a well site. Mostly soft, bentonitic sandstone, with calcareous beds near the top, containing shells and dissociated fish remains.

\section{Locality 3}

Ls. 9, Sec. 9, Tp. 67, Rge. 10, W. 5th M.; road cut at junction of main and side roads. Soft clay and sand, with bone fragments.

\section{Locality 4}

Ls. 4, Sec. 30, Tp. 67, Rge. 10, W. 5th M.; low artificial exposure south of well site. Bentonitic clay and soft, clayey sandstone. Shells of fresh-water mollusks in upper part.

\section{Locality 5}

Ls. 4, Sec. 7, Tp. 67, Rge. 10, W. 5th M.; artificial exposure immediately north of well and battery. Mostly soft, brownish silt with hard beds, one of which has impressions of leaves and twigs.

\section{Locality 6}

Ls. 10, Sec. 4, Tp. 68, Rge. 10, W. 5th M.; large artificial exposure east of well. Brown and grey-brown soft bentonitic sandstone with ironstone. Fragmentary carnosaur teeth.

\section{Locality 7}

Ls. 8, Sec. 9, Tp. 68, Rge. 10, W. 5th M.; road cut on east side of road leading to well. Fragmentary bones, presumably dinosaurian.

\section{Locality 8}

Ls. 10, Sec. 3, Tp. 68, Rge. 10, W. 5th M.; small artificial exposure at well site. Soft sandy, bentonitic clay. Fragmentary carnosaur tooth.

\section{Locality 9}

Ls. 4, Sec. 21, Tp. 68, Rge. 10, W. 5th M.; artificial exposure north of well. Grey soft sandstone, with ironstone pellets, overlain by soft brown sandstone; about 20 feet of vertical exposure. Crocodile tooth and scute fragment.

\section{Locality 10}

Ls. 12, Sec. 23, Tp. 68, Rge. 10, W. 5th M.; road cuts on north side of road. Grey and brown, soft clayey sandstone, with ironstone. Numerous bone fragments, presumably dinosaurian, in upper part.

\section{Locality 11}

Ls. 2, Sec. 26, Tp. 68, Rge. 10, W. 5th M.; road cut on west side of road at top of hill leading into ravine. Soft, brown sandstone, with bones and teeth of carnosaurs. 
Locality 12

Ls. 2, Sec. 29, Tp. 68, Rge. 10, W. 5th M.; small artificial exposure at well. Grey and buff, clayey sandstone and impure clay, with pale grey bone fragments.

\section{Locality 13}

Ls. 4, Sec. 29, Tp. 68, Rge. 10, W. 5th M.; extensive artificial exposure east and north of Kewanee B-44 well. Coarse gravel, overlain by light chocolate-coloured shale with ironstone nodules; fragments of petrified wood and cone impressions.

\section{SYSTEMATIC DESCRIPTIONS}

\section{Kingdom P L AN TAE}

Phylum SPERMATOPHYTA

Class GYMNOSPERMAE

Family TAXODIACAE

Genus Glyptostrobus Endlicher

Glyptostrobus nordenskioldi (Heer)

References: Elatocladus (Cryptomerites?) nordenskioldi (Heer) Bell, 1949, p. 50, pl. 31, figs. 2, 3, 5; Glyptostrobus nordenskioldi (Heer) Brown, 1962, p. 49, pl. 11, figs. 3, 7-22.

Material: Numerous well-preserved leafy twigs from locality 5.

Remarks: The specimens referred to this species show narrow leaves alternately attached on either side of the stem, and diverging from the stem at a very acute angle so that there is very little spreading. Bell (1949, p. 49) described Cryptomerites lambii from the Paskapoo formation; in this the leaves appear to be shorter and to diverge more acutely from the stem. The species $G$. nordenskioldi appears to be characteristic of, if not restricted to, the Paleocene.

\section{Genus Metasequoia Miki}

Metasequoia occidentalis (Newberry)

References: Sequoiites langsdorfi (Brongniart) Bell, 1949, p. 47, pl. 27, figs. 4, 6, pl. 29, figs. 1, 3; Metasequoia occidentalis (Newberry) Chaney, 1951, p. 225, pl. 10, figs. 3-6.

Material: Numerous well-preserved leafy twigs from locality 5.

Remarks: Twigs from the above locality referred to this species show close-spaced leaves diverging widely from the stem in opposing pairs. An interesting discussion of Metasequoia is given by Brown (1962, p. 50). The present species appears to be restricted to the Paleocene. 
Remarks: Fossil mollusks obtained by the expeditions of 1964 and 1965 are not as numerous nor as well preserved as those collected on Wallace Mountain by J. A. Allan in 1918 (Russell, 1926, p. 212). However, they represent the same sort of assemblage, that is, one predominantly of pond or lake, rather than stream, environment. The absence of terrestrial genera from both collections is noteworthy.

Class G A S T R O POD A

Family VIVIPARIDAE

Genus Viviparus Montfort

Viviparus planolatere Russell

References: Russell, 1926, p. 214, pl. 2, figs. 1, 2; Tozer, 1956, p. 53, pl. 4, figs. 7, 8a, 8b.

Material: Imperfect shells from locality 1; at two levels, the lower being in association with vertebrate fossils.

Remarks: The shell of this species is rather trochiform, with pointed apex, and whorls which are flattened peripherally but rounded above and below to the impressed suture. As noted by Tozer (1956, p. 53 ), it is a widespread and apparently characteristic Paskapoo species. The present examples are somewhat crushed and imperfect, but show the distinctive characteristics mentioned above.

Viviparus leai (Meek and Hayden)?

Material: A few imperfect shells from locality 4; not common.

Remarks: Shell fragments from locality 4 include one incomplete viviparid shell which has the well-rounded whorls characteristic of $V$. leai (Meek, 1876, p. 577, pl. 44, figs. 6-6d). However, the surface does not show the revolving rows of minute pits which characterize typical specimens of this species and are well shown in specimens from Wallace Mountain.

Genus Lioplacodes Meek

Lioplacodes nebrascensis (Meek and Hayden)

Material: Numerous crushed and incomplete shells from two levels at locality 1 , the lower occurrence with bones of vertebrates.

Remarks: The involved synonomy of this variable species has been discussed by Russell (1931). The reference to Lioplacodes is by Yen (1946, p. 43). The Swan Hills specimens are close to the typical end 
of the series, as distinct from the more elongate, shouldered L. nebrascensis producta (White). This species is widespread in the Fort Union equivalents, including the Paskapoo formation of central Alberta.

Family PHYSIDAE

Genus Physa Draparnaud

Physa canadensis Whiteaves?

Material: A single, imperfect shell from locality 4.

Remarks: In size, and in form of body whorl the specimen suggests P. canadensis media (Russell, 1926, p. 216). Actually this is just one point in a series, the end members of which are $P$. c. parvaturris Russell and $P$. c. canadensis Whiteaves $(=P$. c. ampla Russell).

This species is widespread in the Paskapoo formation, but also occurs in the St. Mary River formation (Upper Cretaceous) of southwestern Alberta.

A small, incomplete shell of a physid is present in the collection from locality 1 .

Phylum CHORDATA

Class ACTINOPTER Y GII

Family A MIIDAE

Genus Protamia Leidy, 1873

Protamia sp.

Material: Fragmentary maxilla and dentary, dentigerous bone, vertebral centrum; from upper part of section at locality 2.

Remarks: The maxilla is from the left side and is incomplete in front and behind. The anterior part is edentulous and tapering, but behind this the lower margin bears 10 tooth sockets, the anterior ones being subcircular, the posterior ones transversely ovoid. This specimen is very similar to a right maxilla figured by Cope (1884, pl. 4, figs. 1d, 1a) and referred to Pappichthys plicatus, but the Swan Hills example is a little more robust, with larger tooth sockets. The fragment of dentary shows little of the bone form but has four tooth sockets, three of which are subcircular. These are of about the same size as those of a dentary fragment referred by Cope (1884, pl. 3, fig. 3) to Pappichthys laevis. The dentigerous bone fragment has many very small, bluntly conoid denticles, not arranged in any pattern. The vertebral centrum is relatively large, with the transverse diameter wider than the vertical. The outline in anterior or posterior view is not regularly avoid, but subtrigonal, the lower margin forming two sides of the triangle, but the ventral angle is truncated by a flat facet. This specimen is of about the same size and nearly the same outline as a vertebra referred by Cope (1884, pl. 2, fig. 54) to Pappichthys sp.

Cope's species to which reference has been made were based on specimens from the Middle Eocene, but the genus is known from the 
Upper Eocene down to the Lancian Cretaceous. Specimens have been found in the Paleocene of the central Alberta foothills (Russell, 1928, p. 107).

Romer and Fryxell (1928, p. 524) have argued convincingly that Cope's genus Pappichthys is not separable from Leidy's Protamia, and this conclusion is accepted here.

The Swan Hills specimens represent a relatively large fish for a freshwater environment, and suggest a lake or large river in contrast to the ponds that seem to have been the home of Stylomyleodon.

Genus Stylomyleodon Russell, 1928

Stylomyleodon sp.

Material: Numerous dentigerous bone fragments and individual teeth; associated with these are fragmentary maxillae and dentaries, many vertebral centra, and rhombic ganoid scales; common at locality 1, rare at locality 2 .

Remarks: The teeth show the characteristic form described in the type, with short cylindrical base and slightly expanded, subglobose crown. Size of individual teeth varies from 3 to $0.5 \mathrm{~mm}$ in maximum diameter. The clusters of teeth still in place on pieces of dentigerous bone show no pattern of arrangement, except that in some cases there is a change in size in one direction. Some groups of teeth show worn crowns. Also present are bone fragments with small, subconical teeth, like those of the modern Amia, and it may be that this genus or something close to it is also present in the fauna.

The jaw fragments include four incomplete maxillae and two pieces of dentaries. None has teeth, but there are numerous sockets or bases, which vary in shape from subcircular to quadrangular-ovoid. Although of small size, these jaw fragments seem proportionately more robust than the dentary associated with the type species, and more like the jaws described by Jordan (1927) as Kindleia fragosa.

The vertebral centra are small, and compressed anteroposteriorly as compared with most fish vertebrae. The majority are subcircular in outline, but some have the vertical dimension longer and some the transverse dimension. There is no definite evidence from these vertebrae that more than one kind of fish is represented.

The scales are puzzling, as were those associated with the type species. They are typical ganoid scales, like those of Lepisosteus, but the outline is more nearly rectangular, suggesting the scales of palaeoniscoids. The presence of such scales on an amiid would be anomalous, but the possibility, at least, must be considered.

The nomenclature of this fish is unsettled. The writer's original manuscript description of Stylomyleodon lacus disappeared from the Post Office in New Haven, and came back mysteriously many years later from Philadelphia. While a second set of illustrations was being prepared and 
the new manuscript printed, David Starr Jordan (1927) published an account of fish jaws and teeth from the upper part of the Edmonton formation, which he named Kindleia fragosa. He based his species on a dentary, but associated with it pillar-shaped teeth that were identical with the type of Stylomyleodon. A year later (Russell, 1929 B) I called attention to the association in the Lower Eocene of Stylomyleodon teeth with a maxilla different from those of Kindleia fragosa, and having the same dentition as the dentary associated with Stylomyleodon. However, the question of generic distinction is not absolutely settled, and until it is, I prefer to use the name Stylomyleodon, almost in the sense of a form genus, to designate the very characteristic inner dentition. Future discoveries, it is hoped, will establish whether or not these teeth belong to the same fish as do the dentaries of Kindleia.

Class R E P T I L I A

Order CROCODILIA

Family CROCODY LIDA E

Genus and species undetermined

Material: Tooth, and scute fragment, from locality 9.

Remarks: The tooth is relatively high and slender, evidently from the anterior part of the tooth row. It is similar to teeth of the crocodile Leidyosuchus Lambe (1908), the common genus in the Upper Cretaceous and Paleocene of western Canada.

Order SAURISCHIA

Family DEINODONTIDAE

Genus and species undetermined

Material: Fragmentary teeth from localities 6,8 and 11.

Remarks: As far as can be determined from such imperfect specimens, these teeth are identical with those of the well-known genera Gorgosaurus and Albertosaurus. They do not suggest an unusually large size, such as might be expected for Tyrannosaurus.

Family ORN I T HOMIMIDAE

Genus Ornithomimus Marsh, 1890

Ornithomimus sp.

Material: The proximal phalanx of digit III, from locality 11.

Remarks: This specimen is similar in size and form to the corresponding bone of Ornithomimus ingens (Parks, 1933, p. 13), from the Edmonton formation of the Red Deer River valley, Alberta. 
Class M A M M A L I A

Order MULTITUBERCULATA

Family PTILODONTIDAE

Genus Ectypodus Granger and Simpson, 1929

Ectypodus cochranensis (Russell).

References: Ptilodus cochranensis, Russell, 1929A, p. 172, fig. 1; Ectypodus cochranensis, Russell, 1932, p. 49, figs. 1-5.

Material: ROM No. 05601, right $\mathrm{P}^{4}$; ROM No. 05602, incomplete left $\mathrm{P}_{4}$; ROM No. 05603, left $\mathrm{M}_{1}$; all from locality 1.

Description: The $\mathrm{P}^{4}$ in crown view is shallowly crescentic in outline, with bilobate outer margin. The inner or main row of cusps extends as a straight ridge from the anterior end posteriorly and slightly externally for about two-thirds the tooth length, then, at the apex of the ridge, turns obliquely to the posterior extremity. There are nine cusps on the main part of the row. Behind the apex the ridge apparently was smooth to the posterior end, where there was one cusp, now mostly worn away. The outer row of cusps is represented by a single, pointed tubercle about onequarter the tooth length from the anterior end, and by a tiny cusp in front of that tubercle. In external view the inner row of cusps is seen to rise in a straight line from anterior end to apex. Behind this the ridge falls off more steeply, and with a slight concavity, to the posterior end. Length of the tooth is $3.2 \mathrm{~mm}$.

The $\mathrm{P}_{4}$ is represented by the anterior part of the crown back to the third serration, and somewhat farther back below. The anterior margin is curved in side view, and without a groove in front. The concavity for the $\mathrm{P}_{3}$ is more pronounced from internal view than from external. The enamel of the crown extends as a prominent lobe down the outer side of the anterior root. Length of the tooth as preserved is $3.0 \mathrm{~mm}$ and the estimated original length is about $4.5 \mathrm{~mm}$.

The $\mathrm{M}_{1}$ is elongate-ovoid in crown view. There are two rows of cusps, nine in the outer row and five in the inner row, with an additional rudimentary cusp at both front and back of the inner row. The outer cusps are slightly crescentic in outline, with the concavity posterior, whereas the main cusps of the inner row are pyramid-like, with the slope towards the midline slightly excavated in the lower part. In side view the inner row of cusps is seen to project well above the level of the outer row, especially anteriorly. Length of the tooth is $3.2 \mathrm{~mm}$.

Remarks: Reference of these specimens to $E$. cochranensis is inferential. The type of that species is a left $\mathrm{P}_{4}$, which is of about the same size as the incomplete $\mathrm{P}_{4}$ described above. The anterior margin of the crown in the type is less curved, but otherwise the resemblance seems close. Subsequently additional teeth from another locality were referred to this species. These included a $\mathrm{P}^{4}$, an $\mathrm{M}^{1}$ and an $\mathrm{M}_{2}$, along with several $\mathbf{P}_{4}$. The association of all these teeth in the one species was provisional. 
The $\mathrm{P}^{4}$ is a little smaller than the Swan Hills specimen described above, and the main cusp row is a little less elevated and pointed. There are two less cusps in the inner row and one more in the outer. Such differences could be within the range of individual variation. Whether or not the Swan Hills $\mathrm{P}^{ \pm}$really belongs to $E$. cochranensis, the association of this tooth with the $M_{1}$ seems reasonable, as these two teeth are of about the same length, and this is the relationship in several species of Ectypodus (McKenna, 1960, p. 35).

Ectypodus cf. laytoni Jepsen.

Reference: Jepsen, 1940, pp. 304-307, fig. 17, pl. 4, figs. 1-3.

Material: ROM No. 05604, anterior half of left $\mathrm{P}_{4}$, from locality 1.

Description: This tooth is very small. It is broken away vertically at the fourth serration, so that the complete outline of the cutting edge is not determinable but it was evidently high. In front of the first serration the outline is gently curved, with one small bump. Junction with the anteroventral margin of the crown is subangular. On the external side the anteroventral margin extends posteroventrally as an almost straight line, slightly concave in the lower part, and meets the ventral margin at an acute, blunt angle. Internally the anteroventral margin of the crown is much shorter. Viewed from in front the anterior face of the crown is a narrow triangle, with rounded surface. Below this is a slight concavity for a small $P_{3}$. The lateral surfaces of the crown show all or part of six curved ridges extending anteroventrally from the serrations. The ridge from the first serration is short, and converges towards the lower end of the second ridge. Length of the $P_{4}$ as preserved is $1.6 \mathrm{~mm}$; the estimated length when complete is about $3.3 \mathrm{~mm}$.

Remarks: Reference of this tiny tooth fragment to Ectypodus is based on the form of the anterior face of the crown and on the slight convexity of the surface adjacent to $\mathrm{P}_{3}$. The diverging ridges from the first serration, usually mentioned in the generic diagnosis, are not evident, but the surface here is somewhat worn. The small size limits comparisons to less than half of the described species. Of these, only E. laytoni Jepsen (1940, p. 304) shows the same subangular downward prolongation of the external enamel surface in the vicinity of the anterior root. The ridges on the sides of the crown in ROM No. 05604 seem to be orientated at a slightly lower angle than in the typical $\mathrm{P}_{4}$ of $E$. laytoni. That species is from the Silver Coulee beds of the Polecat Bench formation of Park County, Wyoming, and is of Late Paleocene (Tiffanian) age.

Genus Anconodon Jepsen, 1940

Anconodon sp.

Material: ROM No. 05605, anterior half of left $\mathrm{P}_{4}$; ROM No. 05606, anterior half of a right $\mathrm{P}_{4}$, locality 1. 
Description: Both specimens have been broken away at about the fifth serration. The crowns have a high upper margin, which, as far as it is preserved, is strongly curved. The narrowly triangular anterior face is rounded, but has a faint, shallow vertical groove in the midline, better developed in No. 05606 than in No. 05605. Below the anterior end of the crown there is a concave overhang that received the $\mathrm{P}_{3}$. The outer enamel surface extends as a rounded lobe well down the side of the anterior root. Length of the right $P_{+}$(No. 05606) as preserved, $2.8 \mathrm{~mm}$; estimated length when complete, about $4.7 \mathrm{~mm}$.

Remarks: Reference of these teeth to Anconodon is based on the presence of a marked concavity for $\mathrm{P}_{3}$, and on the high, curved profile. The faint groove on the anterior face is considered diagnostic of the genus but seems to be a variable feature. In size the Swan Hills teeth are a little smaller than those of Anconodon russelli (Simpson, 1935) but in the anterior profile of the crown more closely resemble the larger species, A. gidleyi (Simpson, 1935). The age of these two species is Middle Paleocene (Montana and Wyoming) but $A$. russelli or something like it has been reported from the early Tiffanian (Late Paleocene) of southcentral Wyoming (Gazin, 1956, p. 14).

Genus Prochetodon Jepsen, 1940

Prochetodon sp.

Material: ROM No. 05607 and No. 05608, incomplete right $\mathrm{P}_{4} \mathrm{~s}$; from locality 1.

Description: The dorsal outline of the crown is low, tending towards a straight line in the midlength region, rather than a regular curve. There are 12 serrations preserved on No. 05607, and six on No. 05608. The anterior margin of the crown is low and curved, and the concavity for the $P_{: 3}$ is shallow, with little overhang. The external enamel does not extend very far down the anterior root and is rounded here. Length of No. 05607 as preserved is $4.3 \mathrm{~mm}$, and the estimated length when complete is about $5.6 \mathrm{~mm}$.

Remarks: These specimens are referred to Prochetodon because of the low, flattened dorsal outline of the crown and the slight anterior concavity with little overhang. The size apparently is smaller than that of the $\mathrm{P}_{4}$ of $P$. cavus Jepsen (1940, p. 310) from the Upper Paleocene (Silver Coulee beds) of Park County, Wyoming. There is a slight possibility that the genus is represented in the Lower Eocene of northwestern Colorado (McKenna, 1960, p. 38).

Order INSECTIVORA

Family MIXODECTIDAE

Genus Elpidophorus Simpson, 1927

Elpidophorus elegans Simpson?

Reference: Simpson, 1927, pp. 5-7, figs. 5, 6. 
Material: ROM No. 05609, left upper molar, probably $\mathrm{M}^{1}$; ROM No. 05610, left $\mathbf{P}^{ \pm}$; ROM No. 05611, incomplete left $\mathbf{P}^{ \pm}$; ROM No. 05612, jaw fragment with left $M_{2}$ and incomplete $M_{3}$; ROM No. 05613, left $\mathbf{M}_{3}$; all from locality 1.

Description: The upper molar has an almost rectangular outline, the inner margin being very little oblique, due to the presence of a relatively large hypocone. The protocone is broadly $\mathrm{V}$-shaped, but the paracone and metacone are U-shaped. The external styles are prominent, the mesostyle incipiently double. Dimensions of this tooth are: anteroposterior, $3.3 \mathrm{~mm}$; transverse, $4.4 \mathrm{~mm}$.

The $\mathrm{P}^{t}$ is rounded-triangular, with the rudimentary hypocone only slightly interrupting the outline. The external margin is oblique, and the paracone is more nearly marginal than the metacone. The parastyle is prominent. Transverse dimension of this tooth is $4.1 \mathrm{~mm}$.

The incomplete $\mathrm{P}^{4}$ appears to be more ovoid than triangular in outline. There is a distinct hypocone but this does not bulge from the margin of the crown. The paracone has a distinctly U-shaped crest. The metacone is mostly broken away. Transverse dimension of the tooth as preserved is $4.4 \mathrm{~mm}$.

The $\mathrm{M}_{2}$ on the jaw fragment lacks the metaconid, and the paraconid is rudimentary. The trigonid crests form a V which is orientated obliquely. The talonid is wider than the trigonid, and the prominent hypoconid projects posteroexternally. The transverse crest from the hypoconid does not quite reach the entoconid, but curves back abruptly to form a distinct posterior shelf, a kind of vestigial hypoconulid. There is a tiny cuspule on the crest near the hypoconid. The $\mathrm{M}_{3}$ on this specimen shows only the protoconid and hypoconid, which are similar to those of $\mathbf{M}_{2}$. The external cingulum does not extend onto the side of the hypoconid. The combined length of $M_{2}$ and $M_{3}$ is $6.8 \mathrm{~mm}$.

The separate $\mathrm{M}_{3}$ is similar to the $\mathrm{M}_{2}$ described above, but has retained the prominent metaconid and has a posteriorly directed hypoconulid about equidistant from hypoconid and entoconid. Length of this tooth is $3.9 \mathrm{~mm}$.

Remarks: Elpidophorus elegans and E. patratus Simpson (1936, p. 11; Upper Paleocene of Montana) are similar in size, so this character does not help in identifying the Swan Hills specimens. Nothing of the upper dentition was found with the types of E. elegans. Comparing the Swan Hills upper molar with those of $E$. patratus one notes a similar size, but a more rectangular outline, which is relatively narrower anteroposteriorly. The mesostyle projects more externally but is not so distinctly double. The crests of the paracone and metacone are U-shaped, rather than $\mathrm{V}$-shaped, giving the ectoloph the shape of a script $W$ rather than a printed $W$.

The two P4, although differing from each other, both differ from the $\mathrm{P}^{4}$ of $E$. patratus in having distinct, although small, hypocones. The complete tooth shows a mesostyle, not present on the $\mathrm{P}^{4}$ of $E$. patratus.

The lower molars described above are distinctly smaller than those 
of both $E$. elegans and $E$. patratus. The paraconid is more reduced than in $E$. elegans and the posterior cingulum of $\mathrm{M}_{2}$ more pronounced. However, the absence of the external cingulum from the hypoconid is more like the condition in E. elegans than in E. patratus.

Reference of the Swan Hills specimens to E. elegans is made with reservations. The upper teeth are of about the same size as those of $E$. patratus but differ in structural details, so they presumably represent either E. elegans or an undescribed species. The lower molars are smaller than those of the two described species but are a little more like those of E. elegans. Again one has the choice of tentative assignment to that species or designation as a new species. With the material available at present the former seems the preferable procedure.

In addition to the teeth described above, there are various tooth fragments from locality 1 that are referable to Elpidophorus sp. Apparently this was one of the more common elements of the Swan Hills Paleocene fauna.

Genus Eudaemonema Simpson, 1935

Eudaemonema, cf. cuspidata Simpson.

Reference: Simpson, 1935B, p. 231.

Material: ROM No. 05614, right $\mathrm{M}^{1}$ or $\mathrm{M}^{2}$, lacking ectoloph; ROM No. 05615, left $\mathrm{M}^{3}$, lacking protocone and intermediaries; from locality 1.

Description: The incomplete right upper molar has a decidedly oblique inner margin, due to the posterointernal projection of the hypocone. The protocone is anteriorly situated, and has a long, curved crest to the V-shaped metaconule. The crest to the protoconule is short, and that cuspule is more lingually located than the metaconule. Anteroposterior dimension of the tooth as preserved is $2.0 \mathrm{~mm}$.

The fragment of the left upper molar is identified as $M^{3}$ because of the extension of the parastyle region anteroexternally. The paracone and metacone are relatively high, and are situated on a W-shaped ectoloph. Length of the specimen as preserved is $2.6 \mathrm{~mm}$.

Remarks: In the right upper molar the anteriorly placed protocone and the obliquely projecting hypocone strongly suggest the $\mathbf{M}^{2}$ of $E$. cuspidatus, although this species has been recorded only from the Middle Paleocene of Montana. The Swan Hills specimen is smaller than the $\mathrm{M}^{2}$ of the type material, and has the protoconule better developed and the crest to the metaconule more curved. The incomplete $\mathrm{M}^{3}$ also resembles the corresponding tooth in E. cuspidatus but the Swan Hills specimen is smaller and has the parastyle even more produced anteriorly. It is probable that the Swan Hills material represents an undescribed species. 
Family LEPTICTIDAE

Genus Diacodon Cope, 1875

Diacodon, cf. minutus Jepsen.

Reference: Jepsen, 1930, pp. 511-513, pl. 9, figs. 7-9.

Material: ROM No. 05616, jaw fragment with left $\mathrm{M}_{3}$; ROM No. 05617, jaw fragment with broken right $\mathbf{M}_{3}$; from locality 1 .

Description: On the left $\mathrm{M}_{3}$ the metaconid is the highest cusp, although this may be due to some wear on the protoconid. It is slightly more buccal in position than the metaconid. The three cusps of the talonid are subequal, the hypoconulid projecting posteriorly, and situated a little closer to the entoconid than to the hypoconid. In side view the trigonid is seen to rise to about twice the height of the talonid. The posterior slope of protoconid and metaconid is straight, and inclined forward from the vertical about $7^{\circ}$. The anterior cingulum starts just buccal to the base of the paraconid, becomes more prominent as it descends obliquely across the anteroexternal side of the crown, and dies out on the internal side below the posterior side of the protoconid base. Length of this tooth is $1.9 \mathrm{~mm}$ and maximum width (trigonid) is $1.2 \mathrm{~mm}$. The right $\mathrm{M}_{3}$ has most of the trigonid broken away. The talonid appears to be almost identical with that of the left $M_{3}$. Length of the tooth as preserved is $1.5 \mathrm{~mm}$.

Remarks: The relative height and the slope of the trigonid, and the position and size of the paraconid suggest the $\mathbf{M}_{3}$ of Diacodon septentrionalis Russell (1929A) from the Paskapoo beds on Bow River, but the size is only about two-thirds that of the latter species. In this respect the closest resemblance is to D. minutus Jepsen from the Tiffanian of Wyoming. In the $\mathrm{M}_{3}$ from the Swan Hills the posterior slope of the trigonid appears more nearly vertical and the paraconid a little better developed. McKenna (1960A, p. 53) regards D. minutus as a species of Leptacodon, but in that genus as I understand it the trigonid is lower and more inclined forward, and the paraconid rather well developed for a leptictid. In $D$. minutus the paraconid is said to be relatively small.

Genus Leptacodon Matthew and Granger, 1921

Leptacodon tener Matthew and Granger?

References: Matthew and Granger, 1921, p. 2; Simpson, 1935A, p. 14, fig. 4 .

Material: ROM No. 05618, jaw fragment with worn right $\mathrm{M}_{2}$ and $M_{: ;}$; ROM No. 05619, jaw fragment with unworn right $M_{: 3}$ and incomplete $M_{2}$; tentatively included, ROM No. 05620, the trigonid of a left lower molar; from locality 1.

Description: On all the molars the trigonid is relatively low, and 
its posterior face is inclined forward about $22^{\circ}$ from the vertical (using the axis from anterior to posterior extremity of the crown as the horizontal datum). The metaconid is a little higher than the protoconid, and has a distinct lingual inclination. From the protoconid a crest curves forward and inward to terminate in a distinct and not much lower paraconid, well spaced from the metaconid and almost as lingual in position. The talonid on $\mathrm{M}_{2}$ is as wide as the trigonid but on $\mathrm{M}_{3}$ it is distinctly narrower. The unworn talonid cusps are sharp and distinct, and the hypoconulid is close to the entoconid and almost as posteriorly projecting on $M_{2}$ as on $M_{3}$. A moderate cingulum is present on the anterior and external sides of the crown, but is interrupted on the external slope of the protoconid. Dimensions, ROM No. 05618: $\mathrm{M}_{2}$, length, $1.4 \mathrm{~mm}$, width, $1.0 \mathrm{~mm} ; \mathrm{M}_{3}$, length, $1.2 \mathrm{~mm}$, width, $0.8 \mathrm{~mm}$.

The isolated left trigonid (No. 05620) shows the same arrangement and development of the cusps as in the complete molars described above, but the width is $1.6 \mathrm{~mm}$.

Remarks: The questioned reference of these specimens to Leptacodon tener is based mainly on the similarity in size. The only important difference between the Swan Hills teeth and those of the holotype from the Tiffany fauna is that the former have the paraconid situated more lingually. The same difference exists with the specimen identified by Simpson (1936, p. 8) as L. cf. tener from the Scarritt Quarry (Tiffanian) of Montana. In this feature the Swan Hills specimens resemble L. ladae Simpson and L. munusculum Simpson (1935B, p. 228) from the Gidley Quarry (Torrejonian) of Montana, but the paraconid is smaller in those species. In L. jepseni McKenna (1960A, p. 51), from the early Wasatchian of Colorado, the paraconids seem to be more anteriorly directed, and the hypoconulid smaller and more nearly median. In L. (Leipsanolestes) siegfriedti Simpson (1928, p. 6), from the Bear Creek fauna (Tiffanian) of Montana the size is larger and the trigonids appear to be lower. The isolated left trigonid (ROM No. 05620) is similar in size to the corresponding part in L. siegfriedti, but better material is needed before that species can be recorded in the Swan Hills fauna.

McKenna (1960A, p. 53) has made some important comments on the species assigned to Leptocodon. Without careful study of the original material I cannot discuss his conclusions as fully as they deserve. However, I have already noted that I do not accept his assignment of Diacodon minutus Jepsen to Leptacodon. I concur in his view that the high, vertical trigonids of Leptacodon packi Jepsen exclude it from that genus. But I regard his conclusion that Leptacodon is an early erinaceoid (McKenna, $1960 B$, p. 157) as not being fully substantiated, and I retain the interpretation of Simpson (1935, p. 14) that Diacodon, Prodiacodon, Leptacodon, and Leipsanolestes [also Xenacodon] are closely related genera of the Leptictidae. I am strongly in agreement with the conclusion of Butler (1956, p. 479) that the Leptictidae represent a distinct branch of insectivores, not directly ancestral to the erinaceoids. Recent discoveries indicate that the leptictoids were differentiated by late Cretaceous time. 
Family PANTOLESTIDAE?

Genus and species undetermined.

Material: ROM No. 05621, trigonid of left lower molar, probably $\mathrm{M}_{1}$; from locality 1 .

Description: The trigonid in outline resembles an equilateral triangle. The anterior and internal sides are gently convex, but the posterior side, above the remnant of the talonid, is widely $\mathrm{V}$-shaped. The three cusps are rather low, triangular-conoid, and well spaced. The protoconid and paraconid are subequal and slightly worn. The metaconid, in spite of its worn or eroded condition, was obviously a little higher than either of the other two cusps. It is directed somewhat backward as well as upward and outward. There is a short, weak cingulum sloping steeply down the anterior face of the paraconid. Width of the trigonid is $2.0 \mathrm{~mm}$.

Remarks: The rounded-triangular shape of the trigonid, and the bluntly conoid cusps suggest the lower molars of pantolestids such as Bessoecetor Simpson (1936) and Aphronorus Simpson (1935B). These genera are represented in the Middle and Upper Paleocene and the Middle Paleocene, respectively, of Montana. Bisonalveus Gazin (1956) from the Upper Paleocene of southern Wyoming also appears to belong to this group. However, the Swan Hills fragment differs from the lower molars in all of these genera in having the metaconid higher than the protoconid. This is such an unusual condition that even the family reference is in doubt.

Order PRIMATES

Family CAR P OLESTIDAE

Genus Carpolestes Simpson, 1928

Carpolestes cygneus, new species. Plate I.

Etymology: Latin cygneus, pertaining to a swan; analogous to Carpolestes aquilae Simpson.

Types: Holotype, ROM No. 05622, right mandibular fragment with $\mathrm{P}_{4}$. Paratypes: ROM No. 05623, left mandibular fragment with $\mathrm{P}_{4}$; ROM No. 05624, left maxillary fragment with $\mathrm{P}^{3}$; all from locality 1.

Definition: Size about two-thirds that of the smallest previously described species. $\mathrm{P}_{4}$ moderately high, with rounded rather than pointed profile; 6 serrations on crest. $\mathrm{P}^{3}$ with anteroexternal angle very little produced anteriorly.

Description: The two lower premolars show the characteristic trenchant form of the $\mathrm{P}_{4}$ in this and related genera. Seen from above the crown is rounded-rectangular in outline, bulging a little posteriorly. The crest is almost straight, and is situated a little lingually of midline. In side view of the tooth this crest is seen to curve gracefully upward and 
backward to a little behind midlength, then slope straight to the posterior extremity. There are three serration-like cusps in front of the apex, a large apical cusp, and two on the posterior slope, the last being terminal. The buccal side of the crown is a smooth slope, faintly furrowed below the interval between the 5 th and last cusps. On the lingual side there is a distinct ridge extending downward and a little forward from each of the 1 st to 5 th cusps, those of the first four almost reaching the base of the crown. The 6îh or last cusp has a vertical ridge descending on both sides, almost forming a posterior cingulum. The lower margin of the crown, on both buccal and lingual sides, is bilobate, with an angular re-entrant at about midlength. Dimensions: holotype $\mathrm{P}_{4}$, length $2.2 \mathrm{~mm}$, width $1.3 \mathrm{~mm}$; paratype $\mathrm{P}_{4}$, length $2.0 \mathrm{~mm}$, width $1.4 \mathrm{~mm}$.

The 3rd and 4th upper premolars in this genus are even more bizarre than the $\mathrm{P}_{4}$, and this is true of the left $\mathrm{P}^{3}$ associated with the holotype of this species. The outline of the crown is trapezoidal, the buccal and lingual sides being parallel, and the anterior and posterior margins converging lingually. The anterior projection at the anteroexternal angle, pronounced in some specimens, is barely noticeable in this. There are four cusps in the outer row, the 1 st and 2 nd being largest, and separated, whereas the 2 nd, 3rd and 4th are connected by a continuous crest. A second row of three cusps lies just lingual to the external row; the anterior cusp is the largest, and is just in from the notch between the 1st and 2nd cusps of the external row. This 1st anterior cusp is separated from the anterior margin by a ridge-like cingulum. Lingual to the second row of cusps the crown is widely and shallowly basined, with only a small, oval cuspule projecting in from the posterior margin near the last cusp of the second row. The inner margin of the crown bears two cusps, of which the anterior is the larger. The anterior cingulum, mentioned previously, continues onto the lingual side of the anterointernal cusp, but ends at the notch between this and the posterointernal cusp. Length of the tooth is $1.6 \mathrm{~mm}$ and the width is the same.

Remarks: I am reluctant to propose new species on the basis of the incomplete and fragmentary material from the Swan Hills Paleocene. However, these three specimens show a set of diagnostic characters which do not fit within the limits of previously described species. So it is more realistic to recognize this by establishing a new species than by trying, however tentatively, to squeeze the specimens into one of the described species.

Of these, Carpolestes dubius Jepsen (1930, p. 520) appears to be the closest, especially in the position and development of the cusps on $\mathrm{P}_{4}$ and $\mathrm{P}^{3}$. In fact, the reference to Carpolestes, rather than to the closely related Carpodaptes, is based on the resemblances to C. dubius. However, the smaller size, and the differently shaped $\mathrm{P}^{3}$, are distinctive. Size also separates the present species from the larger $C$. nigridens and $C$. aquilae of Simpson $(1928,1929)$. In $C$. nigridens the profile of the $\mathrm{P}_{4}$ is pointed, rather than curved, and in $C$. aquilae the $\mathrm{P}_{4}$ (badly worn in the type) is more bulging posteriorly. 
Family P LESIADA P IDAE

Genus Plesiadapis Gervais, 1877

Plesiadapis, cf. gidleyi (Matthew).

References: Nothodectes gidleyi, Matthew, 1917; Plesiadapis gidleyi, Simpson, 1935C.

Material: ROM No. 05625, right upper incisor; ROM No. 05626, left lower incisor; from locality 1.

Description: The upper incisor is robust, and broadly curved, the convex side in front. Part of the root has been broken away but the crown is complete. This carries two cusps, the main one being medial, and in its present, somewhat worn state, spade-shaped. The lesser cusp is on the lateral side of the crown, subterminal, conoid, and directed somewhat backward and outward as well as downward. The enamel of the crown ends a short distance above the base of this cusp, and well above this there is a spur-like cusp projecting downward and backward from the posterior edge of the root. Between this spur and the tip of the main cusp the posterior surface of the tooth, only partly enamel-covered, is distinctly concave, so that looked at from this side the functional part of the tooth is spoonshaped. The anteroposterior diameter of the tooth at the spur is $4.5 \mathrm{~mm}$, and the distance from tip of spur to tip of (worn) main cusp is $5.3 \mathrm{~mm}$.

The lower incisor has a single main cusp, and a long, curved, tapering crown. The functional surface, seen from above, slopes a little from medial to lateral, and is marked off by a strong medial ridge and a weak lateral one. The medial ridge terminates at the base of the crown in a spur-like cusp pointing upward. This is not as prominent as the spur on the upper incisor, and is enamel-covered. The vertical diameter of the tooth at the spur is $4.7 \mathrm{~mm}$, and the length of the crown from the (slightly worn) tip to the base of the spur is $8.0 \mathrm{~mm}$.

A second, right lower incisor, which could be the mate to that described, has most of the crown broken away beyond the spur.

The exact identity of these incisors in the tooth row is not known for certain but it has been suggested that the upper one is $\mathrm{I}^{2}$.

Remarks: Both upper and lower incisors agree so closely in form and size with those of Plesiadapis gidleyi (Matthew, 1917; Simpson, 1935C) that one is inclined to refer them to that species without question. This is the representative of the genus in the Tiffany fauna. However, there are two other species of about the same size that have to be considered. P. dubius (Matthew, 1915B, p. 482), from the Clark Fork fauna of Wyoming, is based on material that does not include the upper incisor. P. fodinatus Jepsen (1930), from the Tiffanian of Wyoming, has a tricuspid upper incisor tip. The only American species that can be confidently ruled out is P. cookei Jepsen (1930), from the Clark Fork. Curiously, no cheek teeth of Plesiadapis have been recognized in the material from 
locality 1 . When these are discovered, it will probably be clear that the Swan Hills representative is either $P$. gidleyi or a new species very similar to it.

Order CARNIVORA

Family MIACIDAE

Genus Didymictis Cope, 1875

Didymictis? sp.

Material: ROM No. 05627, incomplete trigonid of a left lower molar; from locality 1.

Description: Part of both protoconid and metaconid have been broken away behind, but apparently the trigonid when complete was nar-. rowly triangular. The internal margin is widely $\mathrm{V}$-shaped. The paraconid is well developed, projecting forward as well as upward. It is not quite as lingually situated as the metaconid. The protoconid, represented now by only a remnant, was evidently the tallest of the three cusps. The metaconid is distinctly higher than the paraconid. There is a slight, gently sloping cingulum on the anterior side of the crown. Width of the trigonid as preserved is $2.5 \mathrm{~mm}$.

Remarks: A fragment such as this cannot be referred with confidence to any genus, but if the protoconid was the highest cusp, the shape of the trigonid, the relative size and position of paraconid and metaconid, and the form of the anterior cinculum would justify a tentative reference to Didymictis. This genus ranges from the Middle Paleocene to well up in Lower Eocene. It is about the nearest thing that we have to the common ancestor of all the fissipeds. The size of the Swan Hills fragment is intermediate between that of the corresponding parts of D. tenuis Simpson (smaller) and D. microlestes Simpson (larger). These species were described (Simpson, 1935B) from the Middle Paleocene of Montana.

Order CONDYLARTHRA

Family HYOPSODONTIDAE

Genus Litolestes Jepsen, 1930

Litolestes, cf. ignotus Jepsen.

Reference: Jepsen, 1930, pp. 513, 514, pl. 5, figs. 1, 2.

Material: ROM No. 05628, jaw fragment with left $\mathrm{P}_{2}$ to $\mathrm{M}_{1}$; ROM No. 05629, jaw fragment with right $\mathrm{P}_{3}$ to $\mathrm{M}_{1}$; the similarity in size, structure, and degree of tooth wear suggests that these two jaw fragments are from the same mandible; from locality 1.

Description: The double-rooted $\mathrm{P}_{2}$ has a single cusp, from which a faint crest runs down to the anteroexternal extremity, where there is a 
rudimentary marginal cuspule. There is a narrow, shallow heel with a single cuspule a little external to the middle of the posterior margin. The crown is not noticeably expanded adjacent to the heel. $\mathrm{P}_{3}$, in contrast, has the heel area distinctly wider than the more anterior part of the crown. It is larger than the $\mathrm{P}_{2}$ with a more distinct anterointernal cuspule, and a faint crest extending forward from the single cuspule on the heel margin. $\mathrm{P}_{4}$ is a robust tooth, with a large main cusp. The anterointernal cusp ("paraconid") is small but distinct, and there is also a small cuspule corresponding to the metaconid on the posterointernal angle of the main cusp. The relatively wide heel has its single cusp situated at about the middle of the margin. The crown is distinctly wider at the heel than anterior to it.

The $M_{1}$ is nearly rectangular in outline, but the anterior margin is a little oblique. The protoconid is the highest cusp, and is inclined inward, so that its apex is about on the midline of the tooth. The metaconid is situated more posteriorly than the protoconid. The paraconid is distinct, although smaller than the metaconid, and is almost as internally situated. It projects a little forward as well as upward. From the protoconid a crest curved forward, then inward to the paraconid. The talonid is deeply basined. The hypoconid is the largest cusp, and from it a strong crista obliqua extends anterointernally to the trigonid just behind the apex of the protoconid. Between the crista and the trigonid is a deep angular notch in the surface of the crown. The hypoconulid is close to the entoconid, and is distinct but not posteriorly projecting. Dimensions (ROM No. 05628): length, $P_{2}$ to $M_{1}, 4.7 \mathrm{~mm}$; length of $M_{1}, 1.3 \mathrm{~mm}$; width of $\mathrm{M}_{1}, 1.1 \mathrm{~mm}$.

Remarks: The Swan Hills specimens probably represent a new species of Litolestes or a closely related genus. They differ from both L. ignotus Jepsen and L. notissimus Simpson (1936, p. 23) in that the main cusp of the $\mathrm{P}_{4}$ is lower and more massive. The size is smaller than that of either described species, although closer to that of L. ignotus. Another resemblance to $L$. ignotus is the distinct paraconid on $\mathbf{M}_{1}$, and the strongly curved crest joining it to the protoconid.

Family A R C T OC Y ON IDAE

Genus Claenodon Scott, 1892

Claenodon sp.

Material: ROM No. 05630, talonid of left lower molar, probably $\mathrm{M}_{2} ;$ from locality 1.

Description: In addition to the talonid, the specimen shows a small portion of the posterior slope of the metaconid. On this there is an oval pit. The hypoconid is obliquely truncated by wear. There is a tiny pit on the anterointernal side, a curved groove on the anteroexternal edge, and a vertical groove on the external face. The entoconid is broken, but 
was evidently about as large as the hypoconid. There is an oblique oval pit still present on the anteroexternal side. A tiny, pitted hypoconulid is present on the posterior margin, between hypoconid and metaconid. Below this the cingulum is interrupted for a short distance; elsewhere it is well developed, especially around the entoconid. The sides of the crown are smooth except for a little vertical rugosity on the external slope of the hypoconid. Width of the tooth at the talonid is $9.1 \mathrm{~mm}$.

Remarks: This was the first identifiable tooth to be found at locality 1 at the time of discovery in 1964, and permitted an immediate age determination of Middle or Late Paleocene. In spite of its incomplete and worn condition it may be referred to Claenodon with some confidence. Such broad, low-cusped teeth have been found among Paleocene mammals only in the arctocyonids and the phenacodonts, such as Tetraclaenodon. From the latter the present specimen may be distinguished by the orientation of the anterior crest of the hypoconid, which extends almost directly forward, and not obliquely inward and forward. The various pits and grooves on the triturating surface also suggest Claenodon; they result from wear of an originally wrinkled surface.

At the specific level identification is much more difficult. Several species of Claenodon have lower molars of about this size. The genus is best known from the Middle Paleocene (Gidley, 1919) but Gazin (1956) has recorded it from the Upper Paleocene of the Bison Basin, southern Wyoming. The new species that he described from there, $C$. acrogenius, could include, as far as the known structure and size are concerned, the incomplete tooth from the Swan Hills.

Family ARCTOCYONIDAE?

Subfamily OXYCLAENINAE?

Genus and species undetermined.

Material: ROM No. 05631, a mandibular fragment with left $\mathrm{M}_{1}$ and $\mathrm{M}_{2}$; from locality 1.

Description: The teeth are unusually small for an oxyclaenine. The cusps are low and rounded, and the enamel is smooth. The $\mathbf{M}_{1}$ is narrower at the trigonid than at the talonid, and the protoconid is more lingually placed than the hypoconid. There is a tiny pit between protoconid and metaconid. From the front of the protoconid a ridge extends forward, then turns inward to the distinct paraconid, which is well spaced from the metaconid, about as far lingually, but smaller. Between protoconid and metaconid the outer slope of the crown has a deep, V-shaped valley. The talonid is deeply basined. The talonid cusps are not much lower than those of the trigonid, and are well spaced on the crest-like posterior margin, the hypoconulid being a little closer to the entoconid than to the hypoconid. The cingulum extends from a point on the anterior slope just buccal to the paraconid to end just below the valley between protoconid and hypoconid. There are no stylar cusps. 
The $M_{2}$ is similar to the $M_{1}$, but the crown is of about the same width at the trigonid as at the talonid. Protoconid and metaconid are not so close together as in the $\mathbf{M}_{1}$. The paraconid is absent, but the crest that would join it to the protoconid is well developed but closer to the anterior slope of protoconid and metaconid. The pit between protoconid and metaconid is larger. The talonid is almost identical with that of $\mathbf{M}_{1}$, except that the hypoconulid is almost equidistant between hypoconid and entoconid. The cingulum extends a little farther back on the buccal side of the tooth, almost to a point below the hypoconid tip.

Dimensions: length of $\mathrm{M}_{1}, 2.7 \mathrm{~mm}$; width of $\mathrm{M}_{1}$ at trigonid, 2.0 $\mathrm{mm}$; at talonid, $2.1 \mathrm{~mm}$; length of $\mathrm{M}_{2}, 2.3 \mathrm{~mm}$; width of $\mathrm{M}_{2}, 2.1 \mathrm{~mm}$.

In spite of the very small size, these teeth suggest an oxyclaenine because of their low cusps and narrow trigonid. There is a close resemblance in form and disposition of the cusps to the lower molars of Thryptacodon Matthew (1915A; Simpson, 1935D) from the Lower Eocene and Upper Paleocene. However, in addition to being much larger $\left(\mathrm{M}_{1}\right.$ is about $6.5 \mathrm{~mm}$ long) the lower molars in that genus have a distinct metastylid in front of the entoconid. Tricentes Cope (1884; Matthew, 1937) and Mimotricentes Simpson (1937), from the Middle Paleocene, lack the metastylid but have wrinkled enamel. There is no close resemblance of the Swan Hills teeth to those of other oxyclaenines. The reference to that group is probably incorrect, but seems to be the best that can be done at this time.

\section{CORRELATION}

The fragmentary dinosaur teeth and bones from the valley of Moosehorn River (localities $6,7,8,10,11$ ) are indicative only of a Cretaceous age, but may be taken to identify this part of the section as representing the Edmonton formation. The crocodile tooth and scute fragment from locality 9 are not diagnostic of age; from its topographical position this locality could be in either upper Edmonton or lower Paskapoo beds.

The fossil plant, mollusk, and fish remains from Swan River valley suggest the Paskapoo formation but are not really diagnostic. The mammals from locality 1, however, provide conclusive evidence of the geological age. The determinations set forth in the preceding section are listed below, together with the geological and geographical occurrences of what appear to be the closest known relatives.

\section{Identification}

Ectypodus cochranensis (Russell)?

Ectypodus, cf. laytoni Jepsen

Anconodon sp.

Prochetodon sp.

Elpidophorus elegans Simpson?
Occurrence of closest analog.

Upper Paleocene, Alberta

Upper Paleocene, Wyoming

Middle Paleocene, Montana

Upper Paleocene, Wyoming

Upper Paleocene, Wyoming

Upper Paleocene, Alberta

and Montana 
Eudaemonema, cf. cuspidata Simpson

Diacodon, cf. minutus Jepsen

Leptacodon tener Matthew and Granger?

Pantolestid, undetermined

Carpolestes cygneus, new species

Plesiadapis, cf. gidleyi (Matthew)

Didymictis? sp.

Litolestes, cf. ignotus Jepsen

Claenodon sp.

Oxyclaenine, undetermined
Middle Paleocene, Montana

Upper Paleocene, Wyoming

Upper Paleocene, Colorado

Middle and Upper Paleocene,

Montana

Upper Paleocene, Wyoming

Upper Paleocene, Colorado

Middle Paleocene, Montana

Upper Paleocene, Montana

Middle and Upper Paleocene, New Mexico to Montana

From this compilation it is clear that the predominant affinities are with the Upper Paleocene or Tiffanian fauna, which is known from a number of occurrences from southern Colorado to Alberta. The suggestions of a Middle Paleocene age might disappear if better material were available in some cases. However, the Paskapoo assemblages from Bow River valley in southern Alberta also include forms that suggest the Middle Paleocene fauna, along with a preponderance of those with Upper Paleocene affinities. A similar aspect appears in the Paleocene assemblages described by Gazin (1956) from south-central Wyoming. It is probable that the Paskapoo mammals of the Swan Hills, like those from this formation farther south, represent late but not latest Paleocene time.

R E F E R E N C ES

ALLAN, J. A., 1919

Geology of the Swan Hills in Lesser Slave Lake district, Alberta. Geol. Surv. Canada, Sum. Rept. 1918, pt. C, pp. 7-13.

BELL, W. A., 1949

Uppermost Cretaceous and Paleocene floras of western Alberta. Geol. Surv. Canada Bull. No. 13, 237 pp., 67 pls.

BUTLER, P. M., 1956

The skull of Ictops and the classification of the Insectivora. Proc.

Zool. Soc. London, vol. 126, pt. 3, pp. 453-481, figs. 1-8.

BROWN, R. W., 1962

Paleocene flora of the Rocky Mountains and Great Plains. U.S.

Geol. Surv., Prof. Paper 375, 119 pp., 1 fig., 69 pls.

CHANEY, R. W., 1951

A revision of fossil Sequoia and Taxodium in western North America based on the recent discovery of Metasequoia. Amer. Philos. Soc. Trans., vol. 40, pt. 3, pp. 171-263, pls. 1-12.

COPE, E. D., 1875

Systematic catalogue of Vertebrata of the Eocene of New Mexico, collected in 1874. Rept. to Engin. Dept., U.S. Army (Wheeler 1884 Survey), 1875, pp. 5-37.

The Vertebrata of the Tertiary formations of the West. U.S. Geol. Surv. Terr., Rept., vol. 3, 1009 pp., 38 figs., 131 pls. 
GAZIN, C. L., 1956

Paleocene mammalian faunas of the Bison Basin in south-central

Wyoming. Smithson. Misc. Coll., vol. 131, no. 6, 57 pp., 2 figs., 16 pls.

GIDLEY, J. W., 1919

New species of claenodonts from the Fort Union (Basal Eocene) of Montana. Bull. Amer. Mus. Nat. Hist., vol. 41, art. 14, pp. 541-555, figs. $1-10$, pl. 28.

GRANGER, W., AND G. G. SIMPSON, 1929

A revision of the Tertiary Multituberculata. Amer. Mus. Nat. Hist., Buil., vol. 56, art. 9, pp. 601-676, figs. 1-43.

JEPSEN, G. L., 1930

Stratigraphy and paleontology of the Paleocene of northeastern

Park County, Wyoming. Proc. Amer. Philos. Soc., vol. 69, no. 7, 1940

pp. 464-528, figs. 1, 2, pls. 1-10.

Paleocene faunas of the Polecat Bench formation, Park County, Wyoming. Part I. Proc. Amer. Philos. Soc., vol. 83, no. 2, pp. 217-340, figs. 1-22, pls. 1-5.

JORDAN, D. S., 1927

Kindleia a new genus of cichlid fishes from the Upper Cretaceous of Alberta. Canad. Field-Nat., vol. 41, no. 7, pp. 145-147, figs. $1-14$.

LAMBE, L. M., 1908

On a new crocodilian genus and species from the Judith River formation of Alberta. Trans. Roy. Soc. Canada, ser. 3, vol. 1, sec. 4, pp. 219-243, pls. 1-5.

MATTHEW, W. D., 1915A

A revision of the Lower Eocene Wasatch and Wind River faunas. Part I-Order Ferae (Carnivora). Suborder Creodonta. Amer. Mus. $1915 \mathrm{~B}$

Nat. Hist. Bull., vol. 34, art. 1, pp. 1-103, figs. 1-87.

A revision of the Lower Eocene Wasatch and Wind River faunas.

Part IV-Entelonychia, Primates, Insectivora. Amer. Mus. Nat. 1917

Hist., Bull., vol. 34, art. 14, pp. 429-483, figs. 1-52, pl. 15.

The dentition of Nothodectes. Amer. Mus. Nat. Hist., Bull., vol. 37, 1937

art. 33, pp. 831-839, pls. 49-52.

Paleocene faunas of the San Juan basin, New Mexico. Trans. Amer.

Philos. Soc. n.s., vol. 30, 510 pp., 85 figs., 65 pls.

AND W. GRANGER, 1921

New genera of Paleocene mammals. Amer. Mus. Novitates, no. 13,

$7 \mathrm{pp}$.

MCKENNA, M. C., 1960A

Fossil Mammalia from the Early Wasatchian Four Mile fauna,

Eocene of Northwest Colorado. Univ. Calif. Publ. Geol. Sci., vol.

37 , no. 1, pp. 1-130, figs. 1-66.

1960B

The Geolabidinae a new subfamily of Early Cenozoic erinaceoid insectivores. Univ. Calif. Publ. Geol. Sci., vol. 37, no. 2, pp. 131-164, figs. $1-6$. 
MEEK, F. B., 1876

A report on the invertebrate Cretaceous and Tertiary fossils of the upper Missouri Country. U.S. Geol. Surv. Terr, Rept. vol. 9, 629 pp.. 85 figs., 45 pls.

PARKS, W. A., 1933

New species of dinosaurs and turtles from the Upper Cretaceous formations of Alberta. Univ. Toronto Stud., Geol. ser. no. 34, 33 pp., 10 pls.

ROMER, A. S. AND F. M. FRYXELL, 1928

Paramiatus gurleyi, a deep-bodied amiid fish from the Eocene of Wyoming. Amer. Jour. Sci., vol. 16, pp. 519-527, figs. 1, 2.

RUSSELL, L. S., 1926

Mollusca of the Paskapoo formation in Alberta. Trans. Roy. Soc.

Canada, ser. 3, vol. 20, sec. 4, pp. 207-220, pls. 1-3. 1928

A new fossil fish from the Paskapoo beds of Alberta. Amer. Jour. 1929A

Sci., vol. 15, pp. 103-107, figs. 1-4.

Paleocene vertebrates from Alberta. Amer. Jour. Sci., vol. 17, pp. 1929B

$162-178$, figs. $1-5$.

The validity of the genus Stylomyleodon. Amer. Jour. Sci., vol. 17, 1931

pp. 369-371.

Mollusca from the Upper Cretaceous and Lower Tertiary of

Alberta. Trans. Roy. Soc. Canada, ser. 3, vol. 25, sec. 4, pp. 9-19, pls. $1,2$. 1932

New data on the Paleocene mammals of Alberta. Canada, Jour.

Mammal., vol. 13, no. 1, pp. 48-54, figs. 1-12.

SCOTT, w. B., 1892

Revision of the North American Creodonta, with notes on some genera which have been referred to that group. Proc. Acad. Nat. Sci. Philadelphia, 1892, pp. 291-323.

SIMPSON, G. G., 1927

Mammalian fauna and correlation of the Paskapoo formation of

Alberta. Amer. Mus. Novitates, no. 268, 10 pp., 7 figs. 1928

A new mammalian fauna from the Fort Union of southern

Montana. Amer. Mus. Novitates, no. 297, 15 pp., 14 figs. 1929

Third contribution to the Fort Union fauna at Bear Creek, Montana. Amer. Mus. Novitates, no. 345, 12 pp., 5 figs. $1935 \mathrm{~A}$

The Tiffany fauna, Upper Paleocene I.-Multituberculata, Marsupialla, Insectivora, and ?Chiroptera. Amer. Mus. Novitates, no. 795, 19 pp., 6 figs.

1935B

New Paleocene mammals from the Fort Union of Montana. Proc.

U.S. Natl. Mus., vol. 83, no. 2981, pp. 221-244. $1935 \mathrm{C}$

The Tiffany fauna, Upper Paleocene II.-Structure and relationships of Plesiadapis. Amer. Mus. Novitates, no. 816, 30 pp., 11 figs. 
The Tiffany fauna, Upper Paleocene III.-Primates, Carnivora, Condylarthra, and Amblypoda. Amer. Mus. Novitates, no. 817, 1936

28 pp. 14 figs.

A new fauna from the Fort Union of Montana. Amer. Mus. Novitates, no. 873, 27 pp., 16 figs.

1937

The Fort Union of the Crazy Mountain field, Montana and its mammalian faunas. U.S. Nat. Mus., Bull. 169, 287 pp., 80 figs., 10 pls.

TOZER, E. T., 1956

Uppermost Cretaceous and Paleocene non-marine molluscan faunas of western Alberta. Geol. Surv. Canada, Mem. 280, 125 pp., 5 figs., 9 pls.

YEN, T. C., 1946

Paleocene freshwater mollusks from Sheridan County, Wyoming. Amer. Jour. Sci., vol. 244, no. 1, pp. 41-48, pl. 1. 
Carpolestes cygneus, new species

All figures stereoscopic pairs, X 10

PLATE I

1. Right mandibular fragment with $\mathrm{P}_{4}$, holotype, ROM 05622, external view.

2. Same, crown view.

3. Left mandibular fragment with $\mathrm{P}_{4}$, paratype, ROM 05623, external view.

4. Maxillary fragment with $\mathrm{P}^{3}, \mathrm{ROM} 05624$, external view.

5. Same, crown view. 

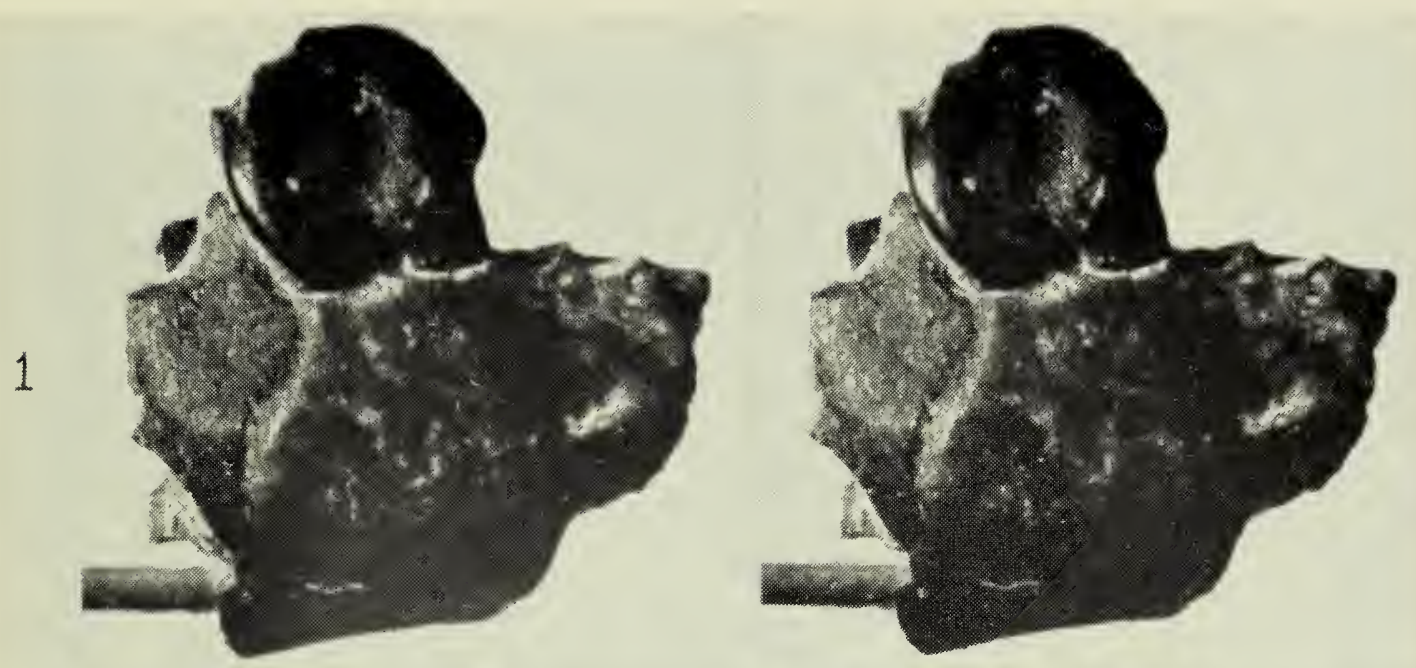

2
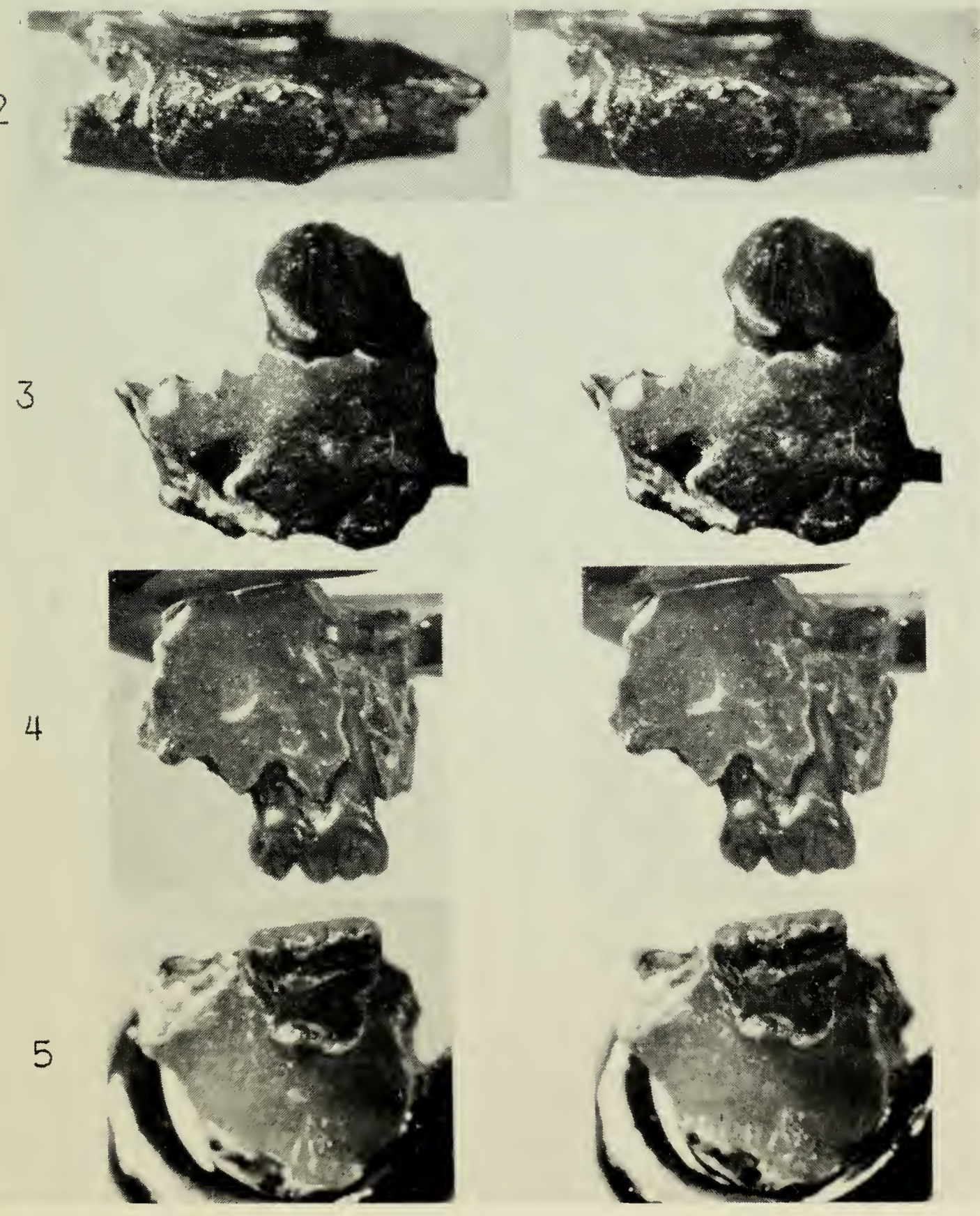


(c) $12^{4}$ - 


\section{LIBRARY}

ROYAL ONTARIO MUSEUM 




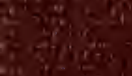

(6)

(at) 